\title{
PSYCHE
}

VOL. XXXIV.

FEBRUARY 1927

No. 1

\section{THE SOCIAL PARASITISM OF THE ANT HARPAGOXENUS AMERICANUS}

By A. H. Sturtevant

Columbia University, New York City.

Harpagoxenus americanus was described by Emery (1895), from workers found by Pergande in a nest of Leptothorax curvispinosus Mayr at Washington, D. C., and from a single specimen collected by Schmitt at Beatty, Pa. Schmitt later informed Wheeler (1910) that this and a few other specimens were taken while he was sifting for beetles. There was no evidence as to their habits or any association with other ants. Wheeler (1905) found three nests at Bronxville, N. Y., that contained H. americanus and $L$. curvispinosus. One nest contained a single Harpagoxenus worker, another six, and the third eight workers and a deälated queen. In 1925 I found a nest (Sturtevant 1925) at Tarpaulin Cove, Naushon Island, Mass., that contained both $H$. americanus and $L$. curvispinosus. So far as I have been able to discover, these are the only recorded occasions on which $\mathrm{H}$. americanus has been collected.

During the summer of $1926 \mathrm{I}$ was fortunate in finding 16 nests of the species, at three different localities in New Jersey. Included in the new material are three kinds of individuals not previously described: males, winged queens, and individuals that look like workers but have rudimentary ocelli. I have also been able to make a few observations on the habits of the species. The present paper contains an account of this new material, with a discussion of the previous data and a comparison with the European species, H. sublavis, studied by Adlerz (1896) and Viehmeyer (1908, 1921). 


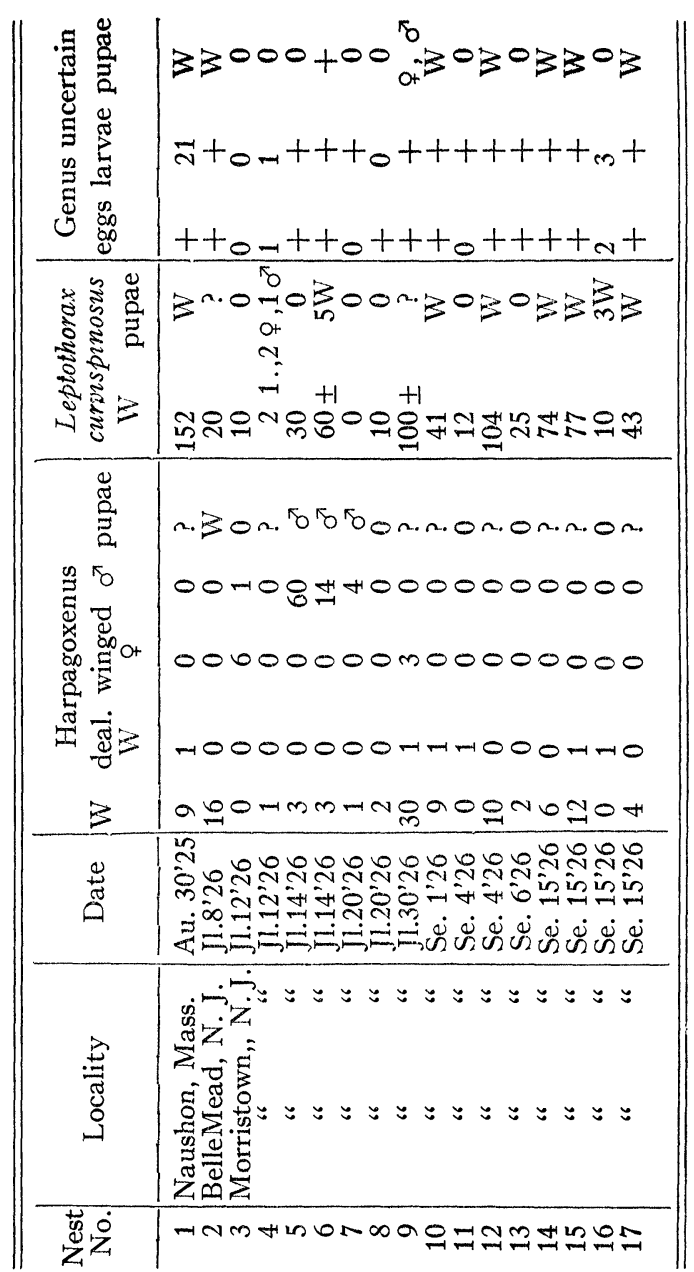

Numbers 7 and 8 each contained a dead Harpagoxenus male.

Number 10 also contained eight workers of Leptothorax longispinosus Roger.

Numbers 1 and 8 taken in oak galls; $2,3,5,6,7$, and 9 in old hickory nuts; 4 , and 10 to 17 inclusive, in old acorns. 
Table 1 gives the statistics for the 17 nests in which $I$ have found Harpagoxenus. Numbers 3 to 9 were found in a small patch of woods near the village of New Vernon, numbers 10 to 17 about four miles away, near Morris Plains. In the first locality 50 pure nests of L. curvispinosus were taken in July and August; in the second 30 were found in September, and at Belle Mead eight pure nests were taken on July 8. I have collected 27 pure nests of L. curvispinosus at various other localities. This gives a frequency of infection of $17: 132=13 \%$. The frequency can hardly be as high as this over most of the range of Harpagoxenus, for the species would then hardly be so rare in collections. It is probably local in distribution, though my success in finding it in four localities suggests that it may be commoner in galls and old nuts than in hollow stems, where the host has apparently been most often collected. I have taken only eight host colonies in hollow stems (of sumac and hickory); none of these were parasitized. I have also taken three pure nests of $\mathrm{L}$. longispinosus (one in each of the regions near Morristown where Harpagoxenus was found and the third also near Morristown). None of these were parasitized.

At least two of the nests in Table 1 seem to represent fragments of colonies. Number 3 had no Harpagoxenus workers or deälated queen, but contained six winged queens and one malethe mother of which was therefore not present. Number 7 contained no Leptothorax at all. My observations agree with Wheeler's that Harpagoxenus is quite unable to care for itself, so this colony must have had Leptothorax workers. Perhaps they were out foraging when I collected the hickory nut. Similar observations have been made on pure nests of L. curvispinosus: e. g., over 20 nests have been found that contained no queen. Accordingly I was led to test nests from nuts lying within four or five feet of each other on the ground. In two cases (pure L. curvispinosus) the individuals from such nests showed no hostility whatever to each other, over a period of several days, though they promptly and vigorously attacked workers from nests taken in different localities. In several cases (including a few parasitized nests) such experiments led to mild fighting, which often did not occur for several minutes after the introduc- 
tion of the strange ant, and was not continued long enough to seriously damage either contestant. Such attacks usually took the form of pulling legs or antennæ, without the usual accompaniment of doubling up the abdomen and rolling about the floor of the nest. These data suggest that a colony may break up into two or more daughter nests, and that these then gradually come to react toward each other as strangers. In accordance with this view is the fact that after the mating season ${ }^{1}$ many of the pure nests have from two to twelve dealated queens; but the number of these seems then to decrease, until by the time winged forms are again produced practically no nest has more than one old queen. The data of Table 1 must then be studied with this evidence in mind, for it is clear that the individuals in one nest do not necessarily constitute an entire colony, whether we are dealing with pure or with parasitized colonies.

There are two chief problems concerning $H$. americanus: 1. How are pure colonies of Leptothorax first infected with Harpagoxenus - i. e., what is the method of colony formation? 2. Does an established Harpagoxenus colony recruit new auxiliaries, and, if so, by what method?

On July $31 \mathrm{I}$ removed all but some irregular stumps of the wings of a queen Harpagoxenus (from nest number 9), and placed her in a pure $L$. curvispinosus nest that contained one deälated queen, about 70 workers and brood. The Harpagoxenus queen was attracted by the brood, but was quickly attacked by the workers. She at once became much excited, and moved so rapidly that the workers did not succeed in grasping her, except occasionally by the stumps of wings. She attacked them, but only by "nipping" at the antennæ or legs-never did she get the "bulldog grip" that is so characteristic of antseven of Harpagoxenus workers. These nips were, however, effective, for within half an hour about ten workers had portions of one or both antennæ amputated. Usually the scape was cut in two. The remaining workers in the nest rapidly moved the brood as far as possible away from the invading queen-under

${ }^{1}$ Winged forms of L. curvispinosus were found in the nests from July 8 to July 30 , with one belated male on August 10 . 
natural conditions they would presumably have left the nest entirely. The Leptothorax queen did not fare differently from the workers, and ultimately she was so maimed that she died. It seems probable that under natural conditions she too would have migrated. Battles occurred from time to time for several days, until most of the workers were more or less maimed. The Harpagoxenus queen showed interest in the brood only intermittently, but occasionally rested on it. New workers emerged in a few days, and on August 4 one of these callows was seen to feed the Harpagoxenus queen by regurgitation. The old workers still attacked her, however, and she grew gradually weaker, until she died on August 10.

If one may judge from this experiment, the fertilized queen of $H$. americanus enters a nest of pure Leptothorax and appropriates some of the brood. The workers and queen are attacked, and emigrate probably to find a new nest, taking much of the brood with them. The intruder is then adopted by the workers that emerge from the brood she has appropriated. It may be surmised that nests numbers 11 and 16 represent cases in which this has just happened. In each of these nests there was present a single deälated Harpagoxenus queen, with a few Leptothorax workers, but no Harpagoxenus workers or pupæ.

Nest number 10 constitutes the best evidence that $H$. americanus makes 'slave raids,' for this nest contained, besides nine workers and a queen of Harpagoxenus, two different host species-41 L. curvispinosus and eight $L$. longispinosus. Both Adlerz and Viehmeyer have found nests of the European $H$. subloevis that contained two host species, and they have argued that these could be explained only on the assumption that $H$. sublavis makes raids. Wheeler (1905) found a mixed nest of $L$. curvispinosus and L. longispinosus (without a queen). and argued that if Harpagoxenus parasitized such a nest the result would be like that observed by Adlerz and Viehmeyer, but would not be due to raids. Viehmeyer (1921) has now actually witnessed the raids of $H$. sublcevis, so there is no necessity for explaining away the "triple" nests of that species. It is to be noted that Wheeler's mixed nest was taken at the same place as his Harpagoxenus nests: it therefore seems to be most probable 
that this mixed nest was in reality a portion of a parasitized colony (like number 10), that happened not to include any parasites.

The following experiment also suggests that raids are made by $H$. americanus. On August 2 an island was made by inverting a large pan and surrounding it by a moat. Three small piles of earth were placed on the island, and on each of these was placed a bit of sponge and a few bits of paper. Nest number 9 was placed on one pile of earth, and on each of the others was placed a pure nest of $L$. curvispinosus. The three colonies all became established, in the soil under their respective sponges. By August 10 there was very little loss by drowning in the moat, and relatively seldom were fights between foraging workers seen. Each Leptothorax nest had a single deälated queen, but these and the Harpagoxenus were practically never seen except when the nests were examined by lifting the covering bits of sponge or paper. The ants were fed chiefly on molasses and Drosophila larvæ, and all seemed to be thriving. But by August 21 one pure colony had disappeared and the other was very weak. On September 14 careful search revealed only the one flourishing parasitized colony. At this time there were observed to be some callow workers of Leptothorax present. While no raid was actually observed, it seems probable that both pure colonies were plundered by the Harpagoxenus (or perhaps by the auxiliaries) of the mixed colony, which did not change its position on the island during the course of the experiment.

Another reason for thinking that raids occur is that pupæ and callows of Leptothorax are so regularly present in the parasitized nests.

Winged queens are rare in $H$. sublcevis. Adlerz failed to find any in Sweden, and in Germany Viehmeyer has found only a few. Their place is taken by worker-like forms that usually possess one or more ocelli. Adlerz has observed that these ergatoids mate, and has shown by dissection that they possess spermathecæ and well-developed ovaries. Such ergatoids have not been described in $H$. americarus, and the data show that true queens are common. Wheeler found one deälated queen, and six are recorded in this paper, together with nine winged 
queens. These differ from the workers in the same ways as do the queens of most ant species. In addition, however, I have found a number of workers with rudimentary ocelli. Such specimens were present, for example, in nests 1 and 5. Usually the ocelli are represented in these specimens only by small chitinized humps, but sometimes small lenses are present. The number of these rudiments varies from one to three; the majority of workers do not show any trace of ocelli. Since 11 of the 17 nests found (and three of the four recorded by Emery and Wheeler) contained no deälated queens, one is led to suspect that $\mathrm{H}$. americanus, like $\mathrm{H}$. sublævis, has fertile worker-like females. This view is borne out by observations made on nest number 4 . The only adult Harpagoxenus in this nest was a worker that had two small rudimentary ocelli. When collected, only one egg was found in the nest, but two days later four eggs were present. This observation is not conclusive, since it is not possible to be certain that the three eggs in question were not present all the time; and even if they were newly laid the Leptothorax workers may perhaps have produced them. I have dissected three workers (Harpagoxenus) from nest number 9. There were three ovarioles present in each ovary in all three specimens, and a sac arising from the anterior end of the common oviduct in every specimen is evidently the seminal receptacle. No spermatozoa were present, and no eggs were differentiated in the ovaries; but these specimens came from a nest that had an old queen, and they had been kept alive in the laboratory for three months, so the ovaries may not have been in normal condition. The evidence thus indicates that $\mathrm{H}$. americanus has fertile worker-like females. It remains to be discovered whether these females infect new colonies by the method Viehmeyer supposes to occur in $H$. sublævis. This author surmises that such ergatoid forms take part in raids, and then remain in the raided nest and appropriate the remnants after their nest-mates have returned to the home nest.

It will be seen from table 1 that sexual forms of Leptothorax were present only in nest number 4 , which contained two queen and one male pupæ. The two former emerged after the nest was brought into the laboratory. They were cared for by the 
Leptothorax workers, and were not molested by the Harpagoxenus worker. They were not deälated, as is reported to occur for sexual forms (of both sexes) of the host species that emerge in nests containing $H$. sublowis. However, this nest was not long kept under observation.

My observations on the general behavior of the ants in the parasitized nests agree with those of Wheeler. The Harapagoxenus workers will eat if they happen to stumble onto a drop of food; but they do not forage, and are fed almost entirely by regurgitation from the Leptothorax workers. When the nest is disturbed they do not move the brood, and often are themselves transported by the much smaller Leptothorax workers. When a Leptothorax from a strange colony is put into the nest it is usually attacked by the auxiliaries, though in one case I have seen a Harpagoxenus take part in resisting such an intruder.

The male of $\mathrm{H}$. americanus has not before been recorded. In the case of $H$. sublowis Adlerz did not at first distinguish the males from those of the host; but $\mathrm{H}$. americanus males are strikingly different from those of $L$. curvispinosus in that they are shining black in color, and from those of $L$. longispinosus in that they have pale whitish yellow legs and antennæ. The eggs, larvæ, and newly formed worker pupæ I have not yet succeeded in distinguishing from those of Leptothorax; but worker pupæ nearly ready to emerge may be distinguished by their shoe 3 epinotal spines.

\section{Papers Cited.}

Adlerz, G.

1896. Myrmekologiska studier. III. Tomognathus subloevis Mayr. Bihang, K. Svensk. Vet. Akad. Handl., vol. 21, pp. 3-76.

Emery, C.

1895. Beiträge zur Kenntniss der nordamerikanischen Ameisenfauna. Zool. Jahrb., Abt. Syst., vol. 8, pp. 257-360. Sturtevant, A. H.

1925. Notes on the ant fauna of oak galls in the Woods Hole region. Psyche, vol. 32, pp. 313-314. 
Viehmeyer, H.

1908. Zur Koloniegründung der parasitischen Ameisen. Biol. Centralbl., vol. 28, pp. 18-32.

1921. Die mitteleuropäischen Beobachtungen von Harpagoxenus. Biol. Zentralbl., vol. 41, pp. 269-278.

Wheeler, W. M.

1905. An interpretation of the slave-making instincts in ants. Bull. Amer. Mus. Nat. Hist., vol. 21, pp. 1-16.

1910. Ants: their structure, development and behavior. xxv-653 pp. New York. 

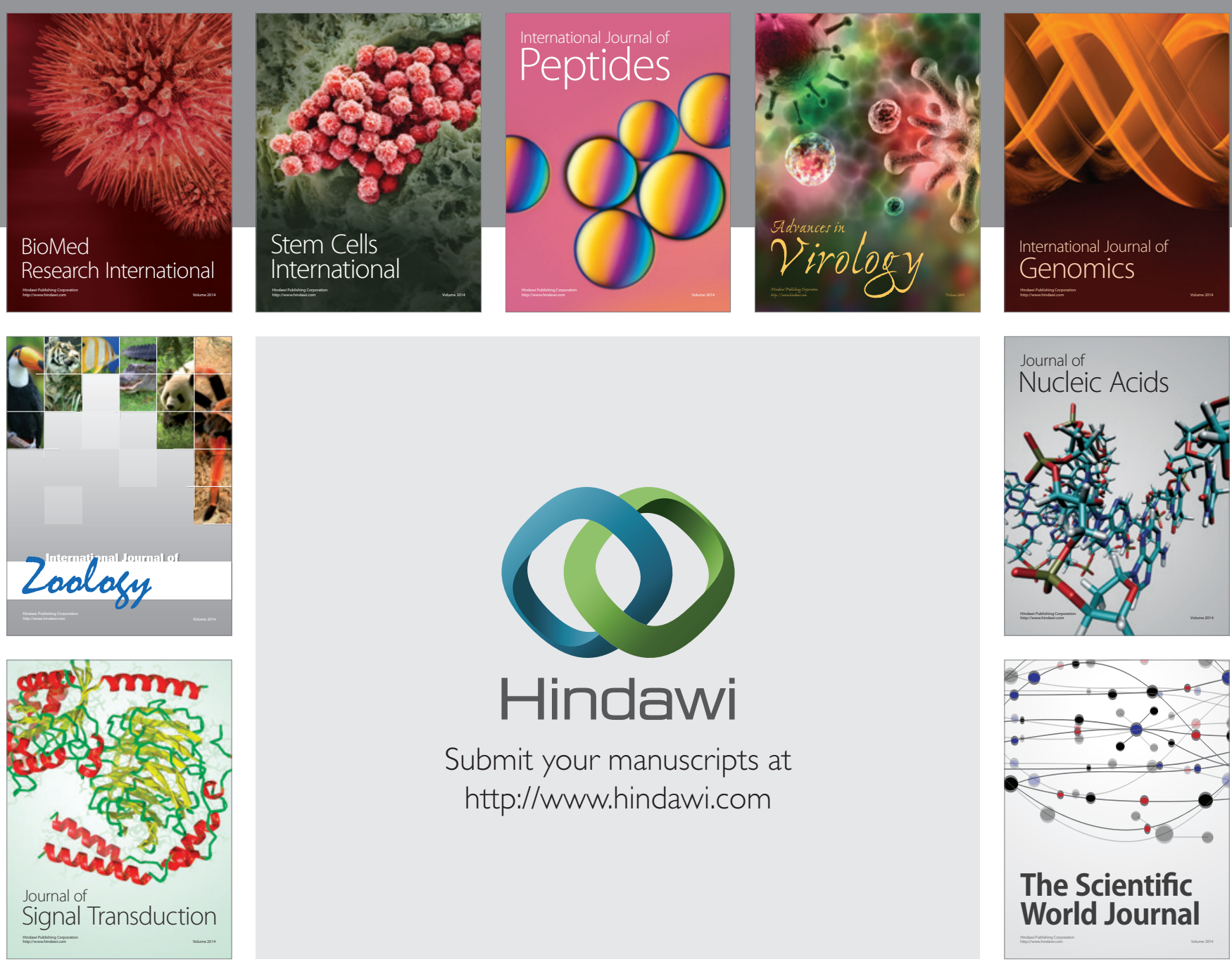

Submit your manuscripts at

http://www.hindawi.com
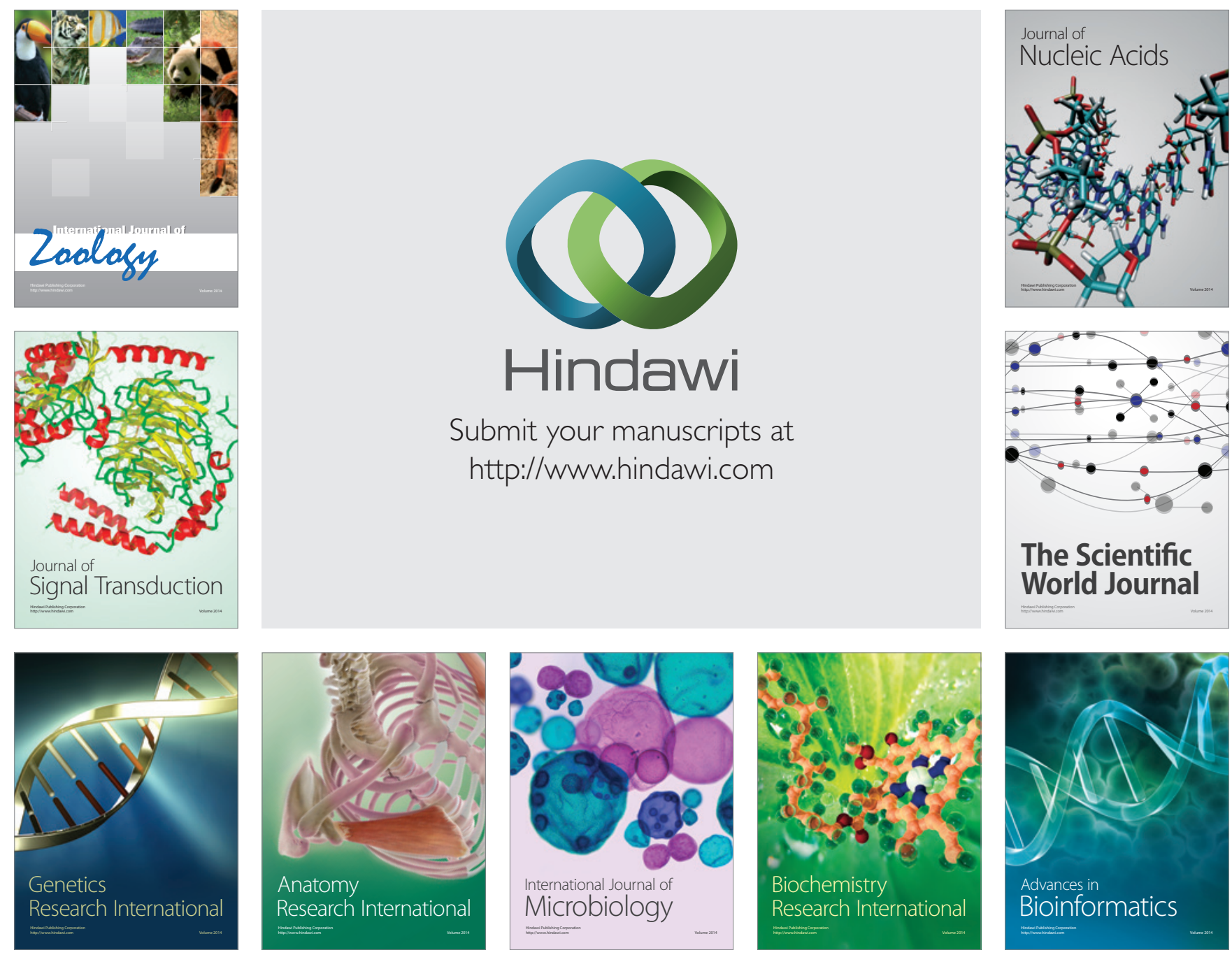

The Scientific World Journal
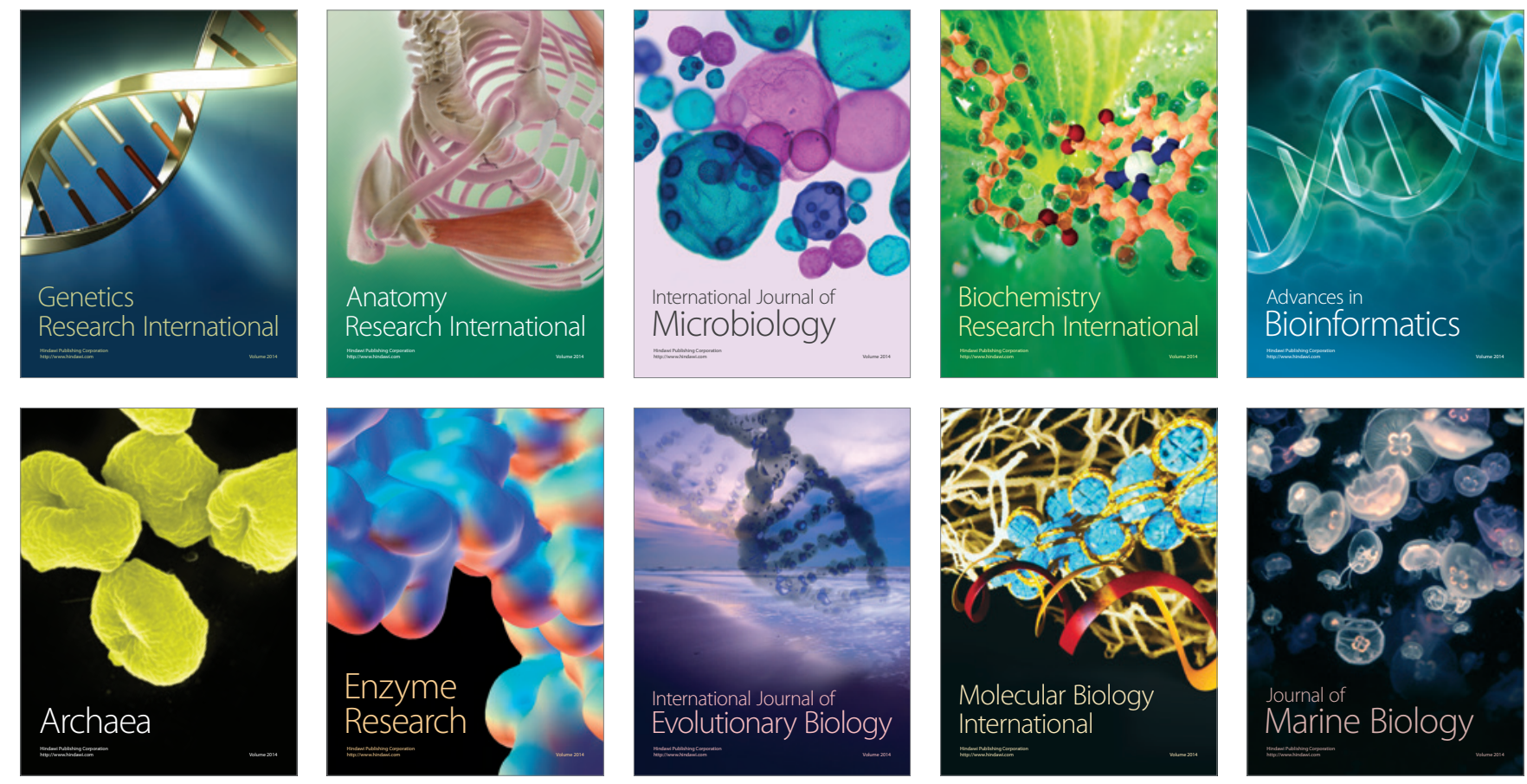